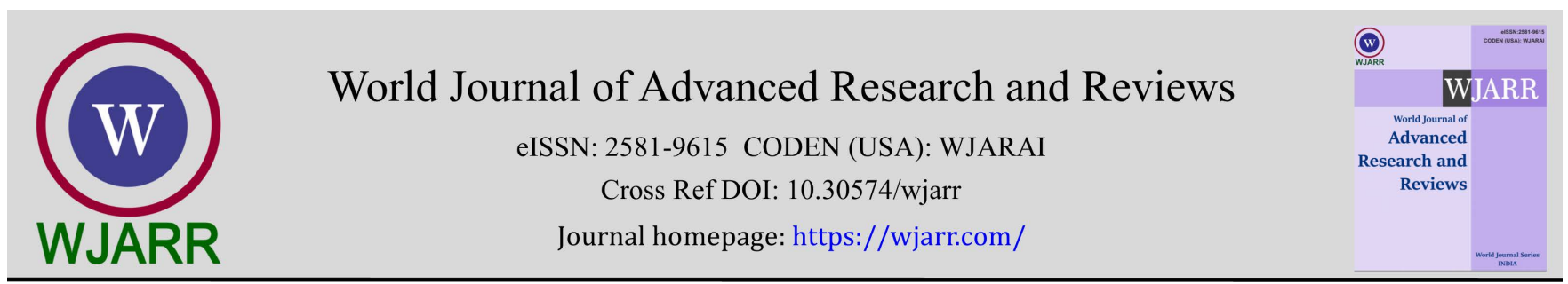

(RESEARCH ARTICLE)

Check for updates

\title{
Influence of the Mekin hydroelectric dam on the distribution of benthic macroinvertebrates of the Dja stream: South Cameroon region
}

\author{
Cécile Rita Boudem Tsane 1, Patrick Georges Thiery Moanono 1, Brillant Nonga Tang 1, Rodrigue Nanfack \\ Dongmo ${ }^{1}$, Paul Bertrand Sob Nangou ${ }^{1}$, Raoul Polycarpe Tuekam Kayo ${ }^{2}$ and Serge Hubert Zébazé Togouet 1,* \\ ${ }^{1}$ Laboratory of Hydrobiology and Environment (LHE), Faculty of Sciences, University of Yaounde I, P.O.Box: 812 Yaounde \\ - Cameroon. \\ ${ }_{2}^{2}$ Biological Sciences, Faculty of Sciences, University of Bamenda, PO Box 39 Bambili - Cameroon.
}

World Journal of Advanced Research and Reviews, 2021, 12(02), 063-077

Publication history: Received on 21 September 2021; revised on 25 October 2021; accepted on 27 October 2021

Article DOI: https://doi.org/10.30574/wjarr.2021.12.2.0552

\begin{abstract}
This work was conducted with the aim of studying the biodiversity of benthic macroinvertebrates in the Dja River and determining the effect of the Mekin hydroelectric dam on their population in relation to the physico-chemical quality of the water. The study ran from May to October 2020 and samplings were carried out on a monthly basis in four different sampling stations located upstream and downstream of the dam. The physico-chemical analyses were done according to standard methods, while the benthic macrofauna was collected using a turbid net of $400 \mu \mathrm{m}$ mesh size over a total area of about $6 \mathrm{~m}^{2}$ per station. Physico-chemical analyses revealed a decreasing evolution from upstream to downstream of the dam of nitrogen forms $\left(\mathrm{NO}_{3}{ }^{-}(1.67 \mathrm{mg} / \mathrm{L}-0.41 \mathrm{mg} / \mathrm{L}) ; \mathrm{NH}_{4}{ }^{+}(0.31 \mathrm{mg} / \mathrm{L}-0.21 \mathrm{mg} / \mathrm{L})\right.$ with p $\left.>0.05\right)$; Electrical Conductivity $(21.45 \mu \mathrm{S} / \mathrm{Cm}-17.1 \mu \mathrm{S} / \mathrm{Cm}$ with $\mathrm{p}<0.05)$ and Suspended Solids $(11.10 \mathrm{mg} / \mathrm{L}-6.57 \mathrm{mg} / \mathrm{L}$ with $\mathrm{p}<0.05)$; while Dissolved Oxygen $(49.82 \%-78.23 \%$ with $\mathrm{p}<0.05)$ and velocity $(0.04 \mathrm{~m} / \mathrm{s}-0.23 \mathrm{~m} / \mathrm{s})$ increased. Organic Pollution Index revealed that the water was moderately polluted (3-4). In total, 1894 individuals, of which 1044 belonging to 2 phyla, 2 classes, 6 orders, 27 families and 47 genera/species were collected upstream; and 850 belonging to 3 phyla, 4 classes, 8 orders, 28 families and 45 genera/species were collected downstream. Odonata was largely abundant and highly represented Trithemis dorsalis (96.05\%); while downstream, Heteroptera was largely abundant and highly represented by Poissonia sp1. (79.78\%). These results revealed that restoration of the upstream of the dam impacted by organic pollution and physical degradation of the environment is recommended.
\end{abstract}

Keywords: Benthic macroinvertebrates; Physico-chemistry; Dja River; Mekin Hydroelectric dam.

\section{Introduction}

The construction of hydroelectric dams has proliferated in the world as a strategy for energy expansion [1]. To produce electricity, these infrastructures need the potential energy of water flows (marine currents, waterfalls, rivers, etc.) [2]; their use leads to changes in the environment, particularly modifications of the banks and water flow regimes, thus promoting impacts of such magnitude that a new ecosystem with completely different properties may be formed $[3,4]$. The impacts of such environmental changes can be assessed through multiple approaches related to the complexity of the receiving ecosystem [5]. Also; methods for assessing river water quality can be physico-chemical and/or biological. Physico-chemical methods, which indicate the causes of disturbances noted at the time of sampling, do not, however, make it possible to predict their effects and are often incomplete in view of the degree of pollution of the discharges [6]. Biological methods, which allow the ecological quality of biotic ecosystems to be assessed, are more integrative and can be based, for example, on the study of aquatic macroinvertebrates. These organisms occupy a wide range of ecological

\footnotetext{
* Corresponding author: Serge Hubert Zébazé Togouet ; Email: zebasehu@yahoo.fr

Laboratory of Hydrobiology and Environment (LHE), Faculty of Sciences, University of Yaoundé I, P.O.Box: 812 Yaounde - Cameroon. 
niches in the aquatic environment; they participate in the process of decomposition of matter that leads to the recycling of nutrients [7] and are bioindicators of the ecological status of hydrosystems [8].

In Cameroon, studies on the characterization of aquatic environments by benthic macroinvertebrates have been carried out in some rivers. These include studies by Foto Menbohan et al. [9, 10,11,12] respectively on the Nga River in the Central South forest ecological region; on an anthropized river in a tropical environment; on the Mfoundi river system and in a periurban stream of Cameroon; Nyamsi Tchatcho $[13,14]$ on the Centre-Southern forest region stream and on the Mefou river system; Onana $[15,16]$ on the rivers of the Wouri river system and on coastal rivers in Cameroon; Tchakonté [17] on urban and peri-urban rivers in Douala; Kengne Fotsing [18] on rivers in the West Cameroon region; Madomguia [19] in the Sudano-Sahelian zone on the Mayo Tsanaga and Mayo Kaliao in the far north of Cameroon; Biram à Ngon et al. [20, 21] in the Mefou watershed and Enah [22] in a few urban streams in the North West Cameroon region. However, in the Southern Cameroon region, these organisms have not been the subject of any characterization study of the hydrosystems and the effect of the Mekin dam on their structure is not known. It is within this framework that the present work is being carried out with the objective of evaluating the influence of the Mekin hydroelectric dam on the diversity and structure of benthic macroinvertebrates in the Dja River.

\section{Material and methods}

\subsection{Study environment}

The study was carried out in the main stream of the Dja watershed and the choice of sampling stations was made according to criteria such as i) accessibility; ii) distance from the dam; iii) activities carried out in the watershed and iv) presence of various microhabitats. Four stations were selected on the river, 2 upstream (D1 and D2) and 2 downstream (D3 and D4) on either side of the dam (Figure 1). The characteristics of each of these stations are shown in Table 1.

Table 1 Characteristics of the different sampling stations

\begin{tabular}{|c|c|c|c|c|c|}
\hline Stations & Geographica & coordinates & Altitude(m) & Speed(m/s) & Physical characteristics \\
\hline D1 & $3^{\circ} 17^{\prime} 09,7^{\prime \prime} \mathrm{N}$ & $12^{\circ} 25^{\prime} 19.7^{\prime \prime} \mathrm{E}$ & 617 & 0.44 & $\begin{array}{l}\text { Submerged dead tree branches and } \\
\text { trunks and macrophytes; } \mathrm{P}=5.17 \mathrm{~m} \text {; } \\
\mathrm{db}=4.82 \mathrm{Km} \text {. }\end{array}$ \\
\hline D2 & $3^{\circ} 16^{\prime} 49.6^{\prime \prime} \mathrm{N}$ & $12^{\circ} 25^{\prime} 00.9^{\prime \prime} \mathrm{E}$ & 600 & 0.44 & $\begin{array}{l}\text { Branches and dead tree trunks } \\
\text { submerged; macrophytes and } \\
\text { canopy present; } \mathrm{P}=4.4 \mathrm{~m} ; \mathrm{db}=1.82 \\
\mathrm{Km} \text {. }\end{array}$ \\
\hline D3 & $3^{\circ} 15^{\prime} 25.3^{\prime \prime} \mathrm{N}$ & $12^{\circ} 25^{\prime} 07.5^{\prime \prime} \mathrm{E}$ & 585 & 0.33 & $\begin{array}{l}\text { Heavy canopy around station, dead } \\
\text { tree trunks; } \mathrm{P}=0.68 \mathrm{~m} \text {; cascading } \\
\text { water flow at dam; } \mathrm{db}=1 \mathrm{Km} \text {. }\end{array}$ \\
\hline D4 & $3^{\circ} 14^{\prime} 16.7^{\prime \prime} \mathrm{N}$ & $12^{\circ} 25^{\prime} 23.2^{\prime \prime} \mathrm{E}$ & 601 & 0.2 & $\begin{array}{l}\text { Station located under canopy, } \\
\text { fishermen's camp; } \mathrm{P}=0.75 \mathrm{~m} ; \mathrm{db}=3 \\
\mathrm{Km} \text {. }\end{array}$ \\
\hline
\end{tabular}

\subsection{Sampling}

Water sampling for physico-chemical analyses and benthic macroinvertebrate was carried out from May to October 2020 on a monthly basis. The water samples for laboratory analysis were taken, against the current, without bubbles, in $1000 \mathrm{~mL}$ polyethylene labeled bottles filled to the brim and double capped; then stored in a refrigerated enclosure and transported to the laboratory. Macroinvertebrate sampling was done following the multihabitat approach proposed by Barbour et al. [23] and Stark et al. [23], which consists of a total of 20 net strokes in different microhabitats per station. Macrofauna were collected using a $30 \mathrm{~cm}$ x $30 \mathrm{~cm}$ beaker, mounted on a $150 \mathrm{~cm}$ long steel handle, and fitted with a conical net with a mesh size of $400 \mu \mathrm{m}$ and $50 \mathrm{~cm}$ depth. At each station, 20 net strokes were done in different micro-habitats and each stroke consisted of pulling the net over a distance of approximately $50 \mathrm{~cm}$ in the opposite direction of the current, i.e. an area of about $6 \mathrm{~m}^{2}$, in a station of about $100 \mathrm{~m}$ in length. Specimens were then collected with a pair of fine tweezers and a hand magnifying glass, and fixed in pillboxes containing $96^{\circ}$ alcohol. 


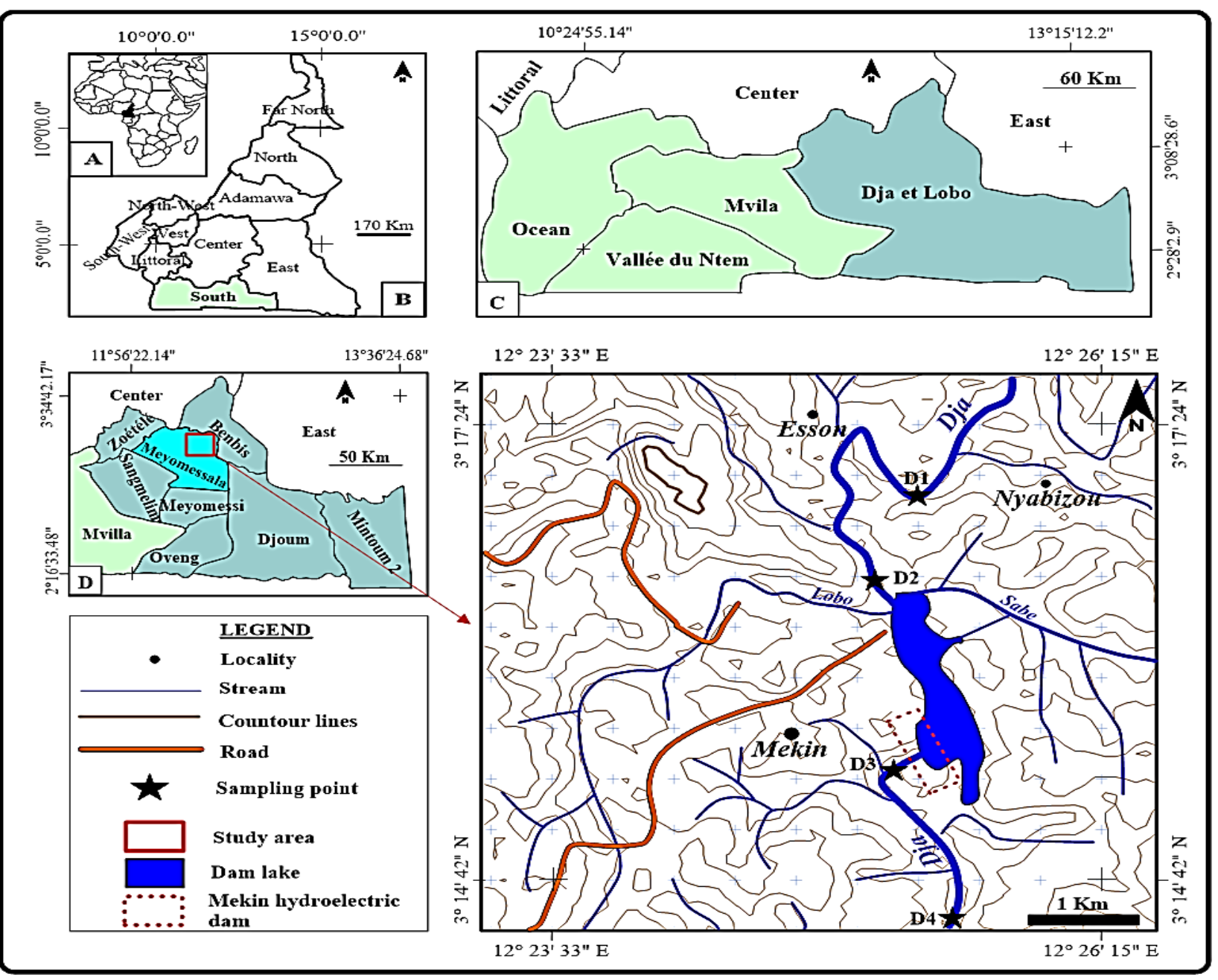

Figure 1 Map of sampling stations upstream and downstream of the dam built on the Dja River.

\subsection{Measurement of hydrological parameters}

The water flow velocity (V) and the water depth were measured in different stations and expressed respectively in meter per second $(\mathrm{m} / \mathrm{s})$ and in meters $(\mathrm{m})$.

\subsection{Measurement of the physico-chemical parameters}

In the field, parameters such as temperature $\left({ }^{\circ} \mathrm{C}\right)$, Dissolved Oxygen $(\%)$ and Electrical Conductivity $(\mu \mathrm{S} / \mathrm{cm})$ were measured with an electronic thermometer, a Hach HQ 30d oximeter and a Water test multiparameter respectively. In the laboratory, parameters such as Suspended Solids (SS) (mg/L), Orthophosphates $\left(\mathrm{PO}_{4}^{3-}\right)(\mathrm{mg} / \mathrm{L}), \mathrm{Nitrates}^{3}\left(\mathrm{NO}_{3}{ }^{-}\right)$ $(\mathrm{mg} / \mathrm{L})$, Nitrites $\left(\mathrm{NO}_{2}\right)(\mathrm{mg} / \mathrm{L})$ and Ammoniacal Nitrogen $\left(\mathrm{NH}_{4}{ }^{+}\right)(\mathrm{mg} / \mathrm{L})$ were measured with a DR 3900 spectrophotometer using the specific reagents.

\subsection{Identification of Specimens}

In the laboratory, the specimens were identified to the lowest possible taxonomic rank (family, genus or species), under a binocular magnifying glass with episcopic illumination of the WILD M3B brand, using determination keys such as those of Durand and Lévêque [25]; Diomandé et al. [26]; De Moor and Day [27]; De Moor et al. [28]; Stals and De Moor [29]; Tachet et al. [30] and Martin and Aït Boughrous [31].

\subsection{Data Analysis}

The normality of the distribution of the samples was verified by using the Kolmogorov Smirnoff and Anova tests at the $5 \%$ threshold, the latter was used when the distribution was normal. The Turkey's pairwise test was applied to identify differences between the stations located upstream and downstream of the dam. These different tests were performed using SPSS version 20.0 and Past version 3.0 software. 
The benthic macroinvertebrate community structure was studied using taxonomic richness and relative abundance. To evaluate the impact of a possible modification of the environment on benthic macroinvertebrates, the Shannon and Weaver $\left(\mathrm{H}^{\prime}\right)$ and Pielou Equitability $(\mathrm{J})$ indices were calculated.

The Shannon and Weaver diversity index was used to assess the diversity at each station and to determine the level of pollution in the section of the river studied. It was calculated according to the formula:

$$
\mathbf{H}^{\prime}=-\sum \mathbf{P}_{\mathbf{i}} \log _{2} \mathbf{P}_{\mathbf{i}},(1)
$$

With $\mathbf{H}^{\prime}=$ Shannon and Weaver diversity index: $\mathbf{P i}=$ relative abundance of taxon i; $\mathbf{n i}$ = relative abundance of taxon i; $\mathbf{N}$ $=$ total abundance.

Piélou's Equitability index (J) (2) was used to measure the equilibrium of the stand while Sörensen's similarity index (3) was used to determine the rate of similarity of the stand between two stations. It was calculated according to the formula:

$$
\mathrm{J}=\frac{H^{\prime}}{\log 2 S}(2) \mathrm{S}=\frac{2 C}{(a+b)} x 100(3)
$$

(2) J = Piélou's Equitability; $\mathbf{H}^{\prime}$ = Shannon and Weaver index and $\mathbf{S}=$ total number of taxa in the sample.

(3) $\mathbf{S}=$ Sörensen's similarity coefficient; $\mathbf{a}=$ number of taxa present in station $1 ; \mathbf{b}=$ number of taxa present in station 2 ; $\mathbf{C}=$ number of taxa common to both stations.

Principal Component Analysis (PCA) was used to establish the abiotic typology of the sampling stations on the basis of all the environmental parameters measured upstream and downstream of the dam. It allowed to present in graphic form, the maximum of the information found in the data table of the environmental variables. This analysis was done using the $\mathrm{R}$ software version 4.0.2. In order to study the relationships between the environmental variables, hydrological and the abundance dynamics of benthic macroinvertebrates, a Canonical Correspondence Analysis (CCA) was carried out from two data matrices, the matrix of hydrological-physicochemical variables, and the matrix of abundances of benthic macroinvertebrate taxa, using Past version 3.0 software.

\section{Results}

\subsection{Physico-chemical parameters}

Dissolved Oxygen showed a significant difference (Turkye's pairwise; $\mathrm{P}<0.01$ ) between upstream and downstream of the dam between stations D1 and D3 and D1 and D4. Its values ranged from 6.4\% to 89.8\% recorded upstream (D1) and downstream (D4) of the dam respectively. Electrical Conductivity values of the water also varied significantly (Anova test; $\mathrm{p}<0.05$ ) from upstream to downstream between stations D1 and D2; D1 and D3 and D1 and D4. Upstream it evolved between $12.67 \mu \mathrm{S} / \mathrm{Cm}$ and $43 \mu \mathrm{S} / \mathrm{Cm}$; while downstream it oscillated between $12.67 \mu \mathrm{S} / \mathrm{Cm}$ and $21.6 \mu \mathrm{S} / \mathrm{Cm}$. The mean value of the water temperature recorded during the study was $27.5 \pm 0.39^{\circ} \mathrm{C}$.

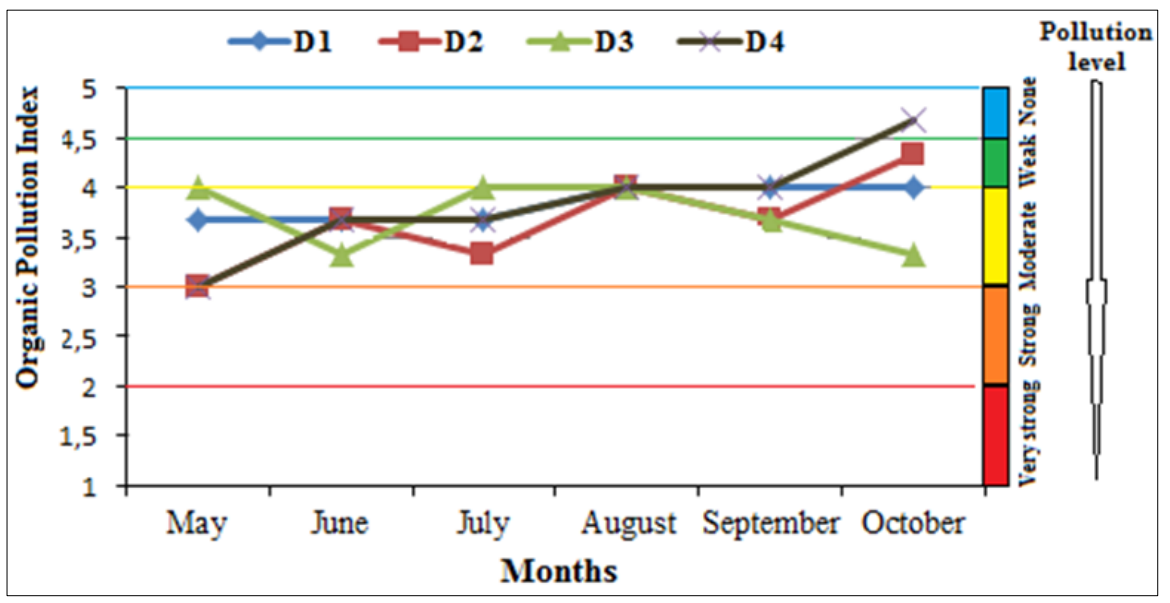

Figure 2 Organic Pollution Index (OPI) of the Dja stream during the study period. 
Upstream peak of $33^{\circ} \mathrm{C}$ was obtained at station D2 while downstream, it was $28^{\circ} \mathrm{C}$ at station D4. Suspended Solids (SS) varied significantly from upstream to downstream of the dam between stations D2 and D3 (Anova test; $\mathrm{p}<0.05$ ). Upstream they fluctuated between $0 \mathrm{mg} / \mathrm{L}$ and $24 \mathrm{mg} / \mathrm{L}$ while downstream they evolved between $1 \mathrm{mg} / \mathrm{L}$ and $18 \mathrm{mg} / \mathrm{L}$. Nitrite levels ranged from $0 \mathrm{mg} / \mathrm{L}$ to $0.02 \mathrm{mg} / \mathrm{L}$ with an average of $0.008 \pm 0.001 \mathrm{mg} / \mathrm{L}$. Extreme levels were recorded at the same station (D2) in July and October respectively. The nitrate concentration of the water fluctuated around an average of $1.04 \pm 0.5 \mathrm{mg} / \mathrm{L}$. The lowest value $(0 \mathrm{mg} / \mathrm{L})$ was obtained at all stations in August and the highest (8.9 mg/L) at the station D1 in September. As for ammoniacal nitrogen; concentrations ranged from $0.03 \mathrm{mg} / \mathrm{L} \mathrm{to} 0.52 \mathrm{mg} / \mathrm{L}$ recorded respectively at station D4 in May and at station D2 in June with an average of $0.25 \pm 0.03 \mathrm{mg} / \mathrm{L}$. Orthophosphate concentration varied up and down around an average of $0.35 \pm 0.1 \mathrm{mg} / \mathrm{L}$ from upstream to downstream of the pier. However, it ranged from $0 \mathrm{mg} / \mathrm{L}$ (D1) to $1.4 \mathrm{mg} / \mathrm{L}$ (D2) upstream and from $0 \mathrm{mg} / \mathrm{L}$ to $2.1 \mathrm{mg} / \mathrm{L}$ (D4) downstream (Table 2).

Table 2 Mean, Min and Max values of physico-chemical parameters evaluated at upstream and downstream during the study period

\begin{tabular}{|c|c|c|c|c|c|c|}
\hline \multirow{3}{*}{\multicolumn{3}{|c|}{ Variables }} & \multicolumn{4}{|c|}{ Sampling stations } \\
\hline & & & \multicolumn{2}{|l|}{ Upstream } & \multicolumn{2}{|l|}{ Downstream } \\
\hline & & & D1 & D2 & D3 & D4 \\
\hline \multirow{16}{*}{ 苞 } & \multirow{2}{*}{ Temperature $\left({ }^{\circ} \mathrm{C}\right)$} & Mean & $26,45 \pm 1,08$ & $28,72 \pm 0,90$ & $26,95 \pm 0,24$ & $26,5 \pm 0,31$ \\
\hline & & Min-Max & $22-30$ & $27-33$ & $26-27,8$ & $26-28$ \\
\hline & \multirow{2}{*}{ Dissolved Oxygen (\%) } & Mean & $37,73 \pm 9,13$ & $61,9 \pm 10,33$ & $79,83 \pm 2,75$ & $76,62 \pm 3,23$ \\
\hline & & Min-Max & $6,4-67,8$ & $18,4-85,5$ & $70-87,7$ & $65,8-89,8$ \\
\hline & \multirow{2}{*}{$\begin{array}{l}\text { Electrical } \\
(\mu \mathrm{S} / \mathrm{Cm})\end{array}$} & Mean & $27,55 \pm 3,47$ & $15,34 \pm 1,59$ & $16,63 \pm 1,46$ & $17,57 \pm 1,42$ \\
\hline & & Min-Max & $19,5-43$ & $12,67-23$ & $12,79-21,6$ & $13,63-22$ \\
\hline & \multirow{2}{*}{ Suspended Solids (mg/L) } & Mean & $11,17 \pm 4,33$ & $11 \pm 1,58$ & $4,8 \pm 2,3$ & $8,33 \pm 2,64$ \\
\hline & & Min-Max & $0-24$ & 8-18 & $1-16$ & $1-18$ \\
\hline & \multirow{2}{*}{$\mathrm{NO}_{2}^{-}(\mathrm{mg} / \mathrm{L})$} & Mean & $0,009 \pm 0,003$ & $0,009 \pm 0,003$ & $0,010 \pm 0,003$ & $0,006 \pm 0,003$ \\
\hline & & Min-Max & $0,001-0,02$ & $0-0,023$ & $0,002-0,022$ & $0,001-0,018$ \\
\hline & \multirow{2}{*}{$\mathrm{NO}_{3}{ }^{-}(\mathrm{mg} / \mathrm{L})$} & Mean & $1,62 \pm 1,46$ & $1,71 \pm 1,38$ & $0,58 \pm 0,45$ & $0,24 \pm 0,14$ \\
\hline & & Min-Max & $0-8,9$ & $0-8,5$ & $0-2,8$ & $0-0,8$ \\
\hline & \multirow{2}{*}{$\mathrm{NH}_{4}{ }^{+}(\mathrm{mg} / \mathrm{L})$} & Mean & $0,297 \pm 0,05$ & $0,31 \pm 0,06$ & $0,22 \pm 0,05$ & $0,19 \pm 0,05$ \\
\hline & & Min-Max & $0,13-0,4$ & $0,11-0,52$ & $0,05-0,37$ & $0,03-0,33$ \\
\hline & \multirow{2}{*}{$\mathrm{PO}_{4}^{3-}(\mathrm{mg} / \mathrm{L})$} & Mean & $0,21 \pm 0,11$ & $0,40 \pm 0,22$ & $0,31 \pm 0,12$ & $0,49 \pm 0,33$ \\
\hline & & Min-Max & $0-0,7$ & $0,04-1,4$ & $0,06-0,8$ & $0-2,1$ \\
\hline
\end{tabular}

The pollution index values obtained during this study varied between 3 and 4.67 with an average of $3.76 \pm 0.16$ showing moderate to low organic pollution (Figure 2) of the Dja stream according to the Leclerf grid [32].

\subsection{Composition of the benthic macroinvertebrate population}

During the study period, a total of 1894 individuals in 03 Phyla (Arthropods (99.21\%), Molluscs (0.74\%) and Annelids $(0.05 \%)), 04$ classes (Insects, Bivalves, Gastropods and Achaetes), 09 orders, 36 families and 65 taxa of benthic macroinvertebrates were collected (Table 3). Of the 65 taxa collected, 62 were identified to genus and/or species level and three to family level. Arthropods had the highest taxonomic richness (92.31\%), followed by Molluscs (6.15\%) and Annelids (1.54\%).

Upstream of the dam, the Order Odonata was the most abundant with $71 \%$ of individuals represented mainly by the species Trithemis dorsalis (with a frequency of occurrence of 96.05\%). Downstream of the dam, the order of Heteroptera 
represented $55 \%$ of the total abundance of the population, mainly represented by the species Poissonia sp1. (with a frequency of occurrence of $79.78 \%$ ) (Figure 3).

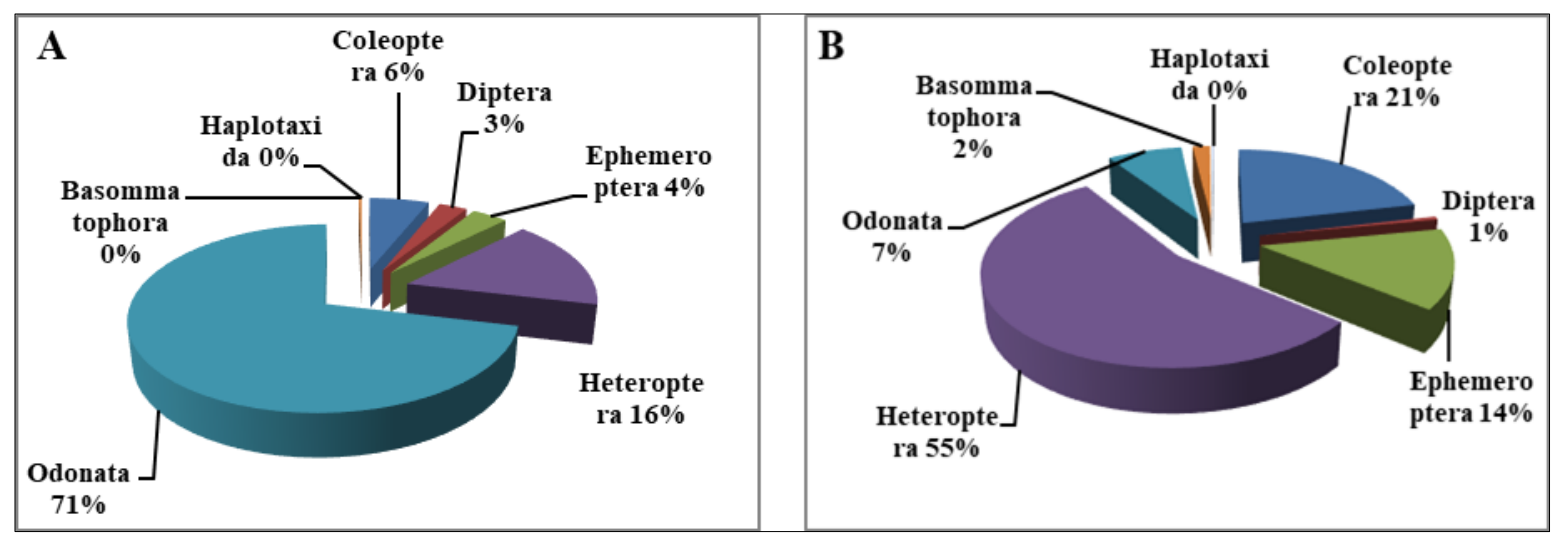

Figure 3 Quantitative distribution of the different orders surveyed upstream (A) and downstream (B) of the dam during the study period.

Table 3 List of benthic macroinvertebrates from the Dja stream collected upstream and downstream of the dam during the study period

\begin{tabular}{|c|c|c|c|c|c|c|c|c|}
\hline \multirow{3}{*}{ Plyla } & \multirow{3}{*}{ Class } & \multirow{3}{*}{ Order } & \multirow{3}{*}{ Family } & \multirow{3}{*}{ Genus/Species } & \multicolumn{4}{|c|}{ Stations } \\
\hline & & & & & \multicolumn{2}{|c|}{ Upstream } & \multicolumn{2}{|c|}{$\begin{array}{l}\text { Downstrea } \\
\text { m }\end{array}$} \\
\hline & & & & & D1 & D2 & D3 & D4 \\
\hline \multirow{18}{*}{$\begin{array}{l}\text { Arthropo } \\
\text { da }\end{array}$} & \multirow{18}{*}{ Insecta } & \multirow{9}{*}{ Coleoptera } & \multirow{2}{*}{ Dytiscidae } & Laccophilus sp1. & 9 & 1 & 9 & 6 \\
\hline & & & & Laccophilus sp2. & 1 & 0 & 1 & 1 \\
\hline & & & Gyrinidae & Aulonogyrus sp. & 0 & 0 & 1 & 0 \\
\hline & & & Hydraenidae & Pterostetops sp. & 2 & 1 & 0 & 0 \\
\hline & & & \multirow{3}{*}{ Hydrophilidae } & Amphiops sp1. & 23 & 3 & 6 & 83 \\
\hline & & & & Amphiops sp2. & 6 & 2 & 0 & 0 \\
\hline & & & & Hydrocyphon sp. & 0 & 1 & 0 & 0 \\
\hline & & & Hygrobiidae & $\mathrm{Ni}$ & 1 & 0 & 2 & 0 \\
\hline & & & Noteridae & Noterus sp. & 12 & 1 & 22 & 51 \\
\hline & & \multirow{6}{*}{ Diptera } & Canacidae & Canas Macateei & 8 & 2 & 0 & 0 \\
\hline & & & Chaoboridae & Dixa sp. & 0 & 1 & 0 & 0 \\
\hline & & & \multirow{2}{*}{ Chironomidae } & Chirononus sp1. & 14 & 2 & 1 & 4 \\
\hline & & & & Chirononus sp2. & 1 & 0 & 0 & 0 \\
\hline & & & Culicidae & Coquillettidia sp. & 1 & 0 & 0 & 0 \\
\hline & & & Tabanidae & Hybomitra epistates & 1 & 0 & 0 & 0 \\
\hline & & \multirow{3}{*}{ Ephemeroptera } & Ameletidae & Ameletus inopinatus & 0 & 0 & 2 & 0 \\
\hline & & & Baetidae & Cleon sp. & 29 & 6 & 2 & 4 \\
\hline & & & $\begin{array}{l}\text { Polymictarcyd } \\
\text { ae }\end{array}$ & Povilla sp. & 0 & 3 & 109 & 1 \\
\hline
\end{tabular}




\begin{tabular}{|c|c|c|c|c|c|c|c|c|}
\hline \multirow{34}{*}{ Plyla } & \multirow{34}{*}{ Class } & \multirow{3}{*}{ Order } & \multirow{3}{*}{ Family } & \multirow{3}{*}{ Genus/Species } & \multicolumn{4}{|c|}{ Stations } \\
\hline & & & & & \multicolumn{2}{|c|}{ Upstream } & \multicolumn{2}{|c|}{$\begin{array}{l}\text { Downstrea } \\
\text { m }\end{array}$} \\
\hline & & & & & D1 & D2 & D3 & D4 \\
\hline & & \multirow{14}{*}{ Heteroptera } & \multirow{2}{*}{$\begin{array}{l}\text { Belostomatida } \\
\text { e }\end{array}$} & Poissonia sp1. & 50 & 36 & 36 & 291 \\
\hline & & & & Poissonia sp2. & 2 & 0 & 0 & 0 \\
\hline & & & Corixidae & Micronecta sp. & 18 & 1 & 9 & 1 \\
\hline & & & \multirow{4}{*}{ Gerridae } & Aquaris sp. & 0 & 0 & 20 & 1 \\
\hline & & & & Gerris sp. & 0 & 0 & 3 & 3 \\
\hline & & & & Neogerris sp. & 1 & 1 & 0 & 11 \\
\hline & & & & Rhagadotarsus sp. & 1 & 0 & 0 & 2 \\
\hline & & & \multirow{2}{*}{ Mesovellidae } & Mesovelia sp. & 0 & 0 & 6 & 2 \\
\hline & & & & Velia sp. & 0 & 0 & 20 & 0 \\
\hline & & & Nepidae & Ranatra Linearis & 4 & 5 & 3 & 7 \\
\hline & & & $\begin{array}{l}\text { Hydrometrida } \\
\text { e }\end{array}$ & Hydrometra sp. & 1 & 0 & 0 & 0 \\
\hline & & & Notonectidae & Notonecta sp. & 28 & 21 & 28 & 16 \\
\hline & & & \multirow{2}{*}{ Veliidae } & Microvelia sp. & 0 & 0 & 5 & 0 \\
\hline & & & & $\mathrm{Ni}$ & 0 & 0 & 1 & 0 \\
\hline & & \multirow{17}{*}{ Odonata } & \multirow{2}{*}{ Aeshnidae } & Anax imperator & 7 & 4 & 0 & 1 \\
\hline & & & & Boyeria irene & 0 & 3 & 0 & 0 \\
\hline & & & \multirow{4}{*}{$\begin{array}{l}\text { Coenagrionida } \\
\text { e }\end{array}$} & Agriocnemis pinheyi & 11 & 12 & 0 & 0 \\
\hline & & & & Cenagrion pro parte & 22 & 36 & 3 & 2 \\
\hline & & & & Ceriagrion tenellum & 12 & 25 & 0 & 0 \\
\hline & & & & $\begin{array}{l}\text { Pseudagrion } \\
\text { spermatum }\end{array}$ & 0 & 1 & 1 & 0 \\
\hline & & & \multirow{3}{*}{ Cordullidae } & Cordulegaster sp. & 0 & 0 & 2 & 0 \\
\hline & & & & Cordulia aenea & 39 & 0 & 0 & 0 \\
\hline & & & & $\begin{array}{l}\text { Phyllomacromia } \\
\text { bifasciata }\end{array}$ & 0 & 0 & 2 & 2 \\
\hline & & & \multirow[t]{2}{*}{ Gomphidae } & $\begin{array}{l}\text { Ceratogomphus } \\
\text { pictus }\end{array}$ & 0 & 0 & 11 & 0 \\
\hline & & & & Ictinogomphus ferox & 0 & 0 & 2 & 0 \\
\hline & & & \multirow{6}{*}{ Libellulidae } & $\begin{array}{l}\text { Crocothemis } \\
\text { erythraea }\end{array}$ & 0 & 2 & 0 & 0 \\
\hline & & & & Libellula sp. & 15 & 94 & 1 & 6 \\
\hline & & & & Macrodiplax cora & 22 & 0 & 2 & 7 \\
\hline & & & & Notiothemis sp. & 4 & 0 & 0 & 0 \\
\hline & & & & Olpogastra sp. & 0 & 0 & 2 & 0 \\
\hline & & & & Orthetrum sp. & 49 & 17 & 1 & 0 \\
\hline
\end{tabular}




\begin{tabular}{|c|c|c|c|c|c|c|c|c|}
\hline \multirow{14}{*}{ Plyla } & \multirow{14}{*}{ Class } & \multirow{14}{*}{ Order } & \multirow{10}{*}{ Family } & \multirow{3}{*}{ Genus/Species } & \multicolumn{4}{|c|}{ Stations } \\
\hline & & & & & \multicolumn{2}{|c|}{ Upstream } & \multicolumn{2}{|c|}{$\begin{array}{l}\text { Downstrea } \\
\text { m }\end{array}$} \\
\hline & & & & & D1 & D2 & D3 & D4 \\
\hline & & & & Pantala flavescens & 1 & 0 & 1 & 0 \\
\hline & & & & $\begin{array}{l}\text { Sympetrum } \\
\text { fonscolombii }\end{array}$ & 5 & 0 & 0 & 1 \\
\hline & & & & Tetratemis sp. & 9 & 89 & 0 & 1 \\
\hline & & & & Tramea transmarina & 25 & 25 & 0 & 0 \\
\hline & & & & Trithemis dorsalis & 53 & 117 & 6 & 1 \\
\hline & & & & Trithemis werneri & 0 & 6 & 0 & 3 \\
\hline & & & & Urothemis sp. & 0 & 16 & 0 & 0 \\
\hline & & & Platycnemidid & Allocnemis sp. & 0 & 0 & 0 & 0 \\
\hline & & & & Platycnemis sp. & 9 & 9 & 4 & 0 \\
\hline & & & Lestidae & Lestes sp. & 1 & 0 & 0 & 0 \\
\hline & & & Synlestidae & Chlorolestes fasciatus & 1 & 0 & 0 & 1 \\
\hline \multirow{4}{*}{ Mollusca } & \multirow{3}{*}{$\begin{array}{l}\text { Gasteropo } \\
\text { da }\end{array}$} & \multirow{2}{*}{$\begin{array}{l}\text { Basommatopho } \\
\text { ra }\end{array}$} & Lymneidae & Stagnicola sp. & 0 & 0 & 0 & 1 \\
\hline & & & Physidae & Aplexa hypnorum & 1 & 2 & 1 & 2 \\
\hline & & $\begin{array}{l}\text { Cycloneritimorp } \\
\text { ha }\end{array}$ & Neritidae & Theodoxus fluviatilis & 0 & 0 & 0 & 1 \\
\hline & Bivalvia & Veneroïda & Sphariidae & Sphaerium sp. & 0 & 0 & 1 & 10 \\
\hline Annelida & Clitellata & Oligocheta & Lumbiculidae & $\mathrm{Ni}$ & 0 & 0 & 0 & 1 \\
\hline \multicolumn{5}{|l|}{ Total } & 499 & 545 & 326 & 524 \\
\hline
\end{tabular}

Ni: Not identified.

\subsection{Ecological Water Quality}

Table 4 shows that the specific richness (S) of macroinvertebrates ranged from 31 to 39. The lowest richness was obtained at station D4 downstream of the dam while the highest was obtained at station D1 upstream. The Shannon diversity index ( $\left.\mathrm{H}^{\prime}\right)$ ranged from 2.47 to 4.46 showing that the stations studied on both sides of the dam were very diversified. The Pielou Equitability Index (J) varied between 0.41 and 0.74 . The lowest value was observed at station D4 downstream and the highest value at station D1 upstream of the pier. This shows that there is a tendency for species exploiting stations D1, D2 and D3 to be in balance, in contrast to those exploiting station D4.

Table 4 Spatial variations in indices describing the structure of benthic macroinvertebrates in the Dja stream upstream and downstream of the dam during the study period

\begin{tabular}{|l|c|c|c|c|}
\hline \multirow{2}{*}{ Characteristics } & \multicolumn{2}{|l|}{ Stations } \\
\cline { 2 - 5 } & \multicolumn{2}{|l|}{ Upstream } & \multicolumn{2}{l|}{ Downstream } \\
\cline { 2 - 5 } & D1 & D2 & D3 & D4 \\
\hline S & 39 & 32 & 35 & 31 \\
\hline Q & 499 & 545 & 326 & 524 \\
\hline H' & 4,46 & 3,64 & 3,68 & 2,47 \\
\hline J & 0,74 & 0,60 & 0,61 & 0,41 \\
\hline
\end{tabular}


$\boldsymbol{S}=$ species richness; $\boldsymbol{Q}=$ abundance $\boldsymbol{\boldsymbol { H } ^ { \prime }}$ = Shannon-Weaver diversity; $\boldsymbol{J}=$ Pielou equitability.

Sörensen's similarity index values remained quite low throughout the study period. They ranged from $3 \%$ to $53 \%$. The highest similarity is observed between stations D1 and D2 (53\%) located upstream of the dam; while the lowest is observed between stations D2 and D3 (3\%) located on either side of the pier.

The Principal Component Analysis (PCA) was performed on the values of six physico-chemical variables and two hydrological variables measured at four (4) stations. The distribution represented by the PCA associating the sampling stations was $61.1 \%$ explained by the first axis and $23.0 \%$ by the second axis (Figure 4 )

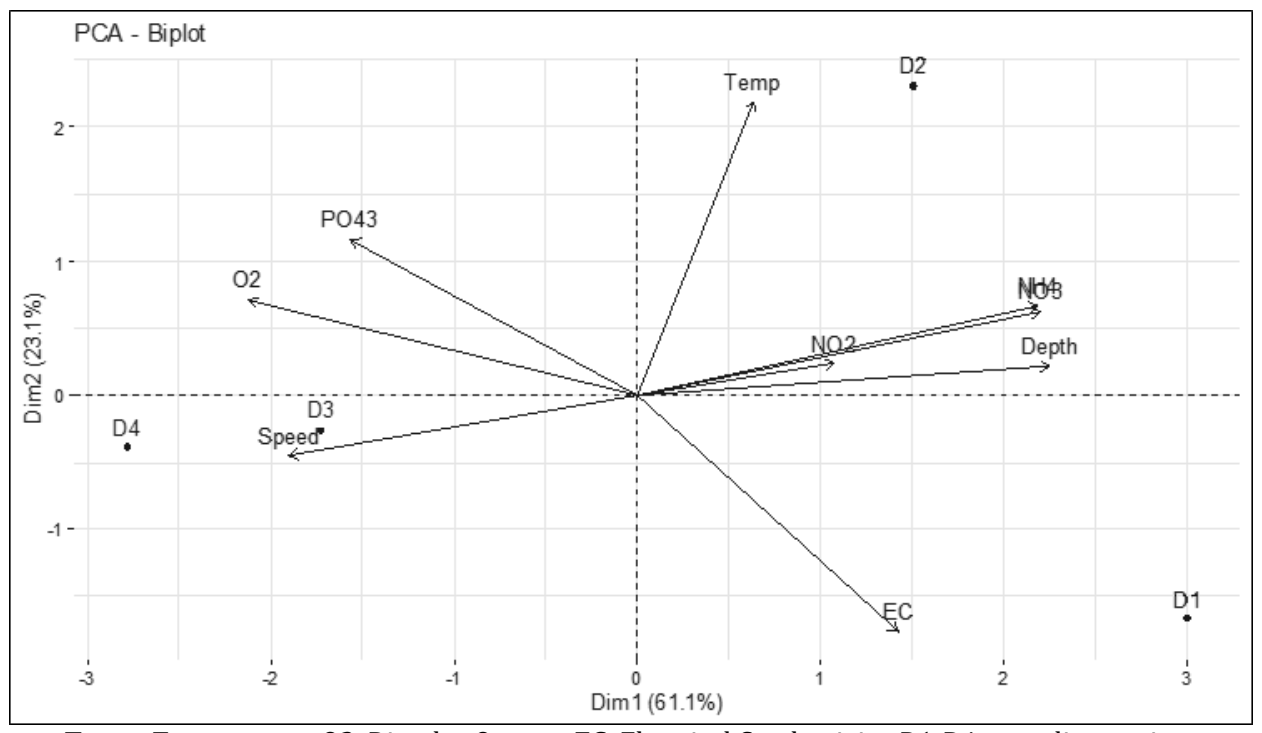

Temp: Temperature, 02: Dissolve Oxygen, EC: Electrical Conductivity, D1-D4: sampling stations

Figure 4 Principal Component Analysis (PCA) of the physico-chemical and hydrobiological variables of the different study stations in the Dja River.

Axis 1 allows us to notice that stations D1 and D2 upstream of the dam were characterized by deep waters rich in nitrate and ammonium nitrogen (Figure 4), suggesting an enrichment of the environment in organic matter. This axis groups the stations located upstream of the dam in its positive part and those located downstream in its negative part. Axis 2 isolates the D2 station located upstream of the dam and characterized by warm and weakly mineralized waters.

The results of the Canonical Correspondence Analysis (CCA) revealed that these variables are mostly distributed around two axis (axis $1=47.37 \%$ and axis $2=36.71 \%$ ) which represent $84.08 \%$ of the total cumulative percentage expressed (Figure 5). The first axis isolates in its positive part, the stations D3 and D4 which are distinguished by moderately oxygenated waters with rapid flow velocity suitable for the installation and proliferation of the taxa Laccophilus sp2. (Lasp2), Amphiops sp1. (Amsp1), Noterus sp. (Nosp), Povilla sp. (Posp), Poissonia sp1. (Poisp), Aquarius sp. (Aqsp), Gerris sp. (Gesp), Neogerris sp. (Nesp) Mesovelia sp. (Mesp) and Sphaerium sp. (Spsp) (Group1). However, in its negative part, this axis isolates the stations D1 and D2 which are distinguished by high temperatures, the nitrate and nitrite contents and the high depths favorable to the development of Pterostetops sp. (Ptsp), Cleon sp. (Clsp), Anax imperator (Aimp), Tetrathemis sp. (Tesp), Tramea transmarina (Ttra), Trithemis dorsalis (Tdor), Trithemis werneri (Twer) and Platycnemis sp (Plsp) (Group2). The second axis is positively and significantly correlated with station D3, nitrite and the taxa Laccophilus sp1. (Lasp1), Povilla sp. (Posp), Aquarius sp. (Aqsp), Mesovelia sp. (Mesp), Noterus sp. (Nosp), Pseudagrion spermatum, Pantala flavescens (Pfl), Platycnemis sp (Plsp). On the other hand, it isolates in its negative part the station D4 characterized by waters rich in Orthophosphates and favorable to the installation of the taxa Amphiops sp1. (Amsp1), Poissonia sp. (Poisp), Neogerris sp. (Nesp), Rhagadotarsus sp. (Rhsp), Chlorolestes fasciatus (Cfas) and Sphaerium sp. (Spsp). 


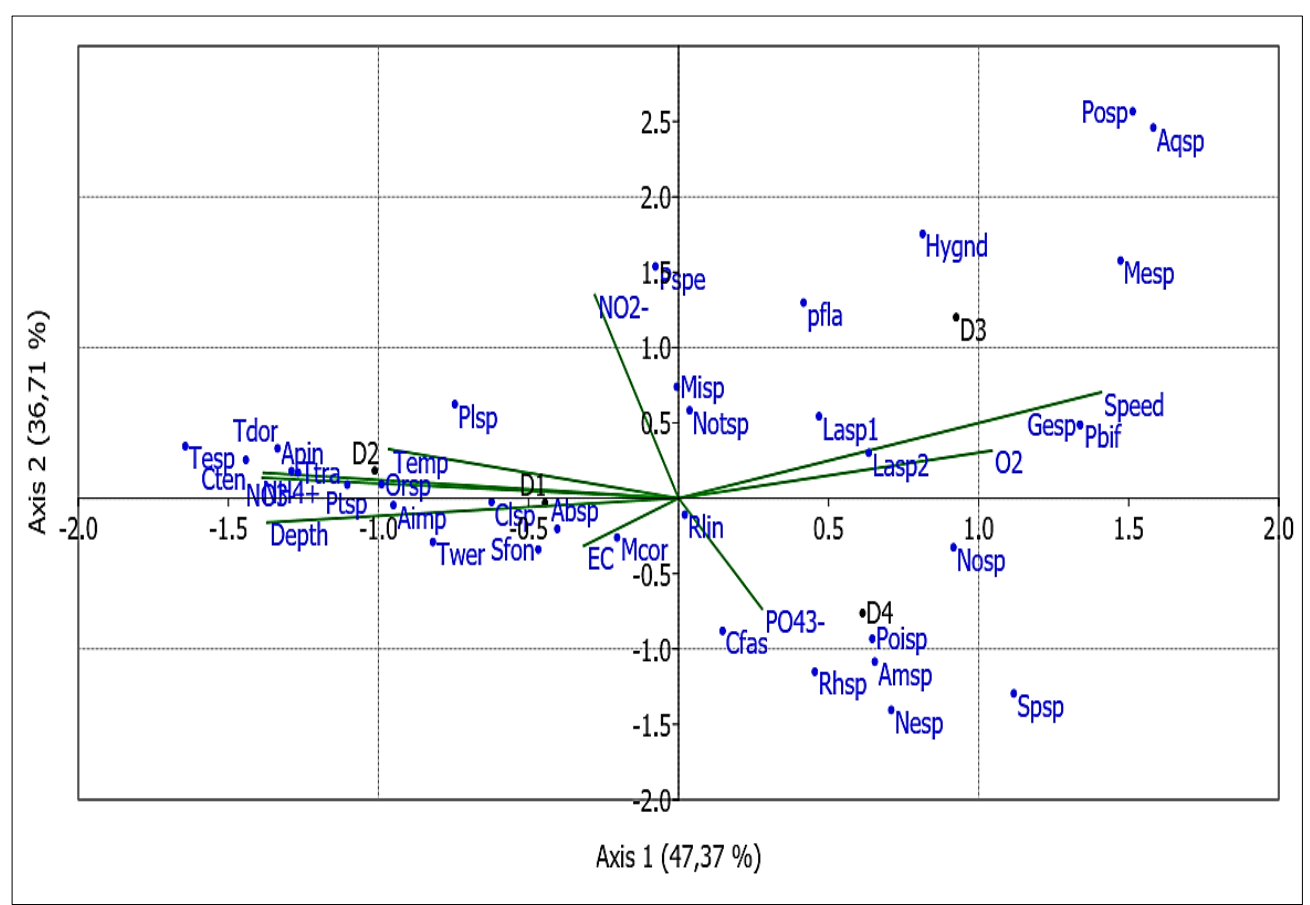

Legend taxon acronyms: Lasp 1 : Laccophilus sp.1, Lasp2 : Laccophilus sp.2, Ptsp : Pterostetops sp., Amsp : Amphiops sp. Hygnd : Hygrobiidae Nd., Nosp : Noterus sp. Absp : Ablabesmyia sp. Clsp : Cleon sp., Posp : Povilla sp., Poisp : Poissonia sp., Misp : Micronecta sp., Aqsp : Aquarius sp., Gesp : Gerris sp., Nesp : Neogerris sp., Rhsp : Rhagadotarsus sp. Mesp : Mesovelia sp., Rlin : Ranatra Linearis, Notsp : Notonecta sp., Aimp : Anax imperator, Apin : Agriocnemis pinheyi, Cten :Ceriagrion tenellum, Pspe : Pseudagrion spermatum, Pbif : Phyllomacromia bifasciata, Mcor : Macrodiplax cora, Orsp : Orthetrum sp., pfla : Pantala flavescens, Sfon : Sympetrum fonscolombii, Tesp : Tetratemis sp., Ttra : Tramea transmarina, Tdor : Trithemis dorsalis, Twer : Trithemis werneri, Plsp : Platycnemis sp., Cfas : Chlorolestes fasciatus, Spsp : Sphaerium sp.

Figure 5 Canonical Correspondence Analysis (CCA) of parameters that regulate the distribution of organisms according to hydrological, physico-chemical and biological similarities in the Dja stream during the study period.

\section{Discussion}

\subsection{Physico-chemical variables}

The average water temperature values at the sampling stations were higher upstream of the dam. These results differ from those of Foto Menbohan et al. [11], Tchakonté [17] and Biram à Ngon et al. [21] obtained on the Nga and Mabounié streams, Nsapè and in some forest streams of the central Cameroon region respectively; but are close to those of Foto Menbohan et al. [33] obtained on some streams in the tropical forest. In fact, it could be related to the direct incidence of sunlight on the water surface due to the absence of canopy upstream. The percentage of dissolved oxygen saturation was higher (79.83 \pm 2.75 and 76.62 \pm 3.23 ) downstream of the dam (stations D3 and D4 respectively). This good oxygenation of the water after dam could be explained by the cascading water flow at the main dam, by the presence of boulders downstream of the dam and by the forested nature of the stream. To this effect, Devidal et al. [34] reveal that in forested areas, the natural ventilation and the presence of riffles are responsible for the creation of conditions of turbulence and water recirculation which are favorable for the reoxygination of water at the water/air interface. Conversely, the low average value $(37.73 \pm 9.13 \%)$ of the percentage of water saturation in dissolved oxygen observed at station D1 upstream could be related to the enrichment of the environment in organic matter from the decomposition of tree trunks immersed in this water body. Cabral-Oliveira et al. [35] point out that high loads of biodegradable organic matter in a river increase the biological, biochemical and chemical demand for oxygen, and therefore a greater consumption of oxygen in the processes of degradation of organic matter by decomposing microorganisms. Furthermore, the up and downstream variability (Turkye's pairwise; $p=0.008$ ) of this parameter at the sampling stations support the idea that the dam induced a change in the environment. Electrical conductivity values remained low throughout the study but showed a significant difference (Anova test; $\mathrm{p}<0.05$ ) between stations D1 where mineralization was highest upstream and the other stations. This could be related to the direct exposure of the upstream part of the dam to solar radiation and the degradation of tree trunks immersed in the water. Indeed, the construction of the Mekin dam on the Dja river in a forested area led to an increase in the water level; thus leading to the destruction of forest trees, and in turn to a direct incidence of sunlight on the water surface. This is supported by Lecerf [36] and Moss [37] who states that the low mineralization of Forest Rivers is due in part to the very rapid cycling of biogenic elements in the forest ecosystem. The data profile of Suspended Solids (SS) is relatively low (0 mg/L - 24 mg/L), but remains 
higher upstream of the dam ( $\geq 11 \mathrm{mg} / \mathrm{L}$ ). The high mineralization obtained upstream could be explained by the falling branches of dead trees in the water that would increase the amount of suspended solids in this reach. These results are similar to those obtained by Tchakonté et al. [17] and Biram à Ngon [38] in peri-urban freshwater (0 mg/L - 15 mg/L) in the city of Douala and in a forest stream $(6.5 \mathrm{mg} / \mathrm{L}$ to $20 \mathrm{mg} / \mathrm{L})$ in the central region of Cameroon respectively.

The moderate to low level of organic pollution observed upstream and downstream of the dam as revealed by the organic pollution index would be related to the contribution of organic substances resulting from the decomposition of tree trunks and dead leaves following, their immersion in water and to the low anthropization of the Dja stream watershed. These results are similar to those obtained by Nyamsi Tchatcho et al. [13] in some reference stations of periurban forest streams in the city of Yaounde, where the level of pollution ranges from moderate to zero. The decreasing water temperature values average contents of the organic pollution indicator parameters (Nitrites, Ammonium and Orthophosphates), water mineralization and the increasing velocity, average dissolved oxygen values from upstream to downstream of the jetty showed that the impacts induced by the construction of the dam are more pronounced upstream, and the forest hydrosystem is gradually and naturally restored downstream of the same dam.

\subsection{Biological variables}

One thousand eight hundred and ninety-four (1894) macroinvertebrates were collected during the study period. Arthropods were the most abundant and represent $92.31 \%$ of the individuals collected (of which the Insect class represents $100 \%$ of the population), followed by Molluscs (6.15\%) and Annelids (0.05\%). According to Foto Membohan et al. [11, 12], Onana [15], Tchakonté [17], Biram à Ngon et al. [21] and Ngoay-kossy et al. [39] these groups of organisms generally reflect the faunal composition of the freshwater macrofauna of Cameroon and Central African Republic. This study reports two classes of organisms (Insects and Gastropods) collected upstream and three classes (Insects, Gastropods and Oligochaetes) collected downstream of the dam. The most abundant class in terms of number of families is Insects ( 31 families) followed by Gastropods ( 3 families) and Oligochaetes ( 1 family). These results are similar to those of Horeau et al. [40] who obtained the larvae of Insects and Oligochaetes at the hydroelectric dam of Petit-Saut on the Sinnamary River in Guyana. The results obtained could be due to the regular input of organic matter [36, 12, 21] from the degradation of tree trunks and branches immersed in the water. In the same way, Milot [41], states that the enrichment of the water in organic matter conditions the growth and development of a small variety of aquatic macroinvertebrates.

Upstream of the dam, the deep stations D1 and D2 which were negatively and significantly correlated with the axis 1 (Figure 5) were predominantly occupied by Odonata of the family Libellulidae and dominated by the species Trithemis dorsalis (96.05\% of the cumulative relative abundance). This could be due to the presence of macrophytes and tree trunks submerged in the water upstream. De Moor et al. [28] and GSED [42] point out that Odonata larvae depend on submerged and emergent vegetated waters for reproduction and live in tree holes filled with water where they feed on mosquito larvae. Downstream however, shallow stations D3 and D4 which were positively and significantly correlated with the axis 1 (Figure 5) are dominated by Heteroptera of the family Belostomatidae and the genus Poissonia (79.78\% of the cumulative relative abundance). Indeed, these predators hidden under the dead leaves present in the water were collected at the level of the banks of the watercourse where the depth does not exceed 1 meter. Simillaly, Polhemus [43] states that Belostomatidae are fond of stream margins where they remain motionless as sitting predator waiting for a prey to come within reach of their legs. These results could be explained by the permanent hydrological changes (flow velocity and water depth) in the hydrosystem induced by the construction of the dam on the stream bed. According to Schriever et al. [44], hydrology is a fundamental factor influencing ecosystem dynamics, life history strategies and diversity patterns in running water habitats. Indeed, the forest and river ecosystem has become an ecosystem with very slow water flow upstream of the dam; thus leading to the installation of organism groups (Odonata) that like this type of environment. Furthermore, Horeau et al. [40] point out the fact that in a slow-flowing aquatic ecosystem, the larvae of dragonflies immago develop above the water body on the supports of plants while the population of invertebrates in the river drops but remains high. Sunlight level, depth, and the presence of submerged and emergent plant substrate have also been considered important factors in invertebrate community structure in the stream [45, 46], as insolation regulates the amount and type of nutrients present [47]; and the presence of plant substrate regulates reproduction [42].

The high values of the Shannon and Weaver indices $(4.46 ; 3.64$ and 3.68$)$ and Pielou's equitability $(0.74 ; 0.60$ and 0.61$)$ at stations D1, D2 and D3 show that from the point of view of pollution, the waters were clean [48, 49] and that the taxa probably have the same abundance in these three stations. According to Foto Menbohan et al. [9], this means that these stations are favorable for the development of benthic macroinvertebrates. Station D4 downstream of the dam indicates slightly polluted water $\left(\mathrm{H}^{\prime}=2.47\right)$ and a predominance of the taxon Poissonia sp1. $(\mathrm{E}=0.41)$ which represents $55.53 \%$ of the individuals collected at this station. This result could be explained by the change in the environment brought 
about by the construction of the dam. Indeed, the upstream part of this structure generally presents a lentic facies dominated by macrophytes and submerged tree trunks, which are practically absent downstream, mainly at the level of station D4. These results corroborate those of Baxter [3] and Agostinho et al. [4] who showed that changes in water flow regimes favor the establishment of new ecosystems with completely different properties (changes in ecosystem functions and services; physical, chemical, geomorphological and hydrological changes of environment and water quality; changes in the structure and dynamics of primary producers, invertebrates and fish as a result of changes in flow, producer dynamics and habitat fragmentation).

Sörensen's Similarity Index shows a similarity rate of 53\% between stations D1 and D2 upstream of the dam; this rate is low (3\%) between stations D2 and D3 located upstream and downstream of the dam respectively. Indeed, stations D1 and D2 have almost the same physical characteristics of the environment (presence of trunks and banks of dead trees, macrophytes immersed in the water and around the stations). However, the dissimilarities of the physical environment observed at stations D2 and D3 coupled with the hydrological change upstream $(\mathrm{V}=0.04 \mathrm{~m} / \mathrm{s} ; \mathrm{P}=4.4 \mathrm{~m})$ and downstream $(\mathrm{V}=0.33 \mathrm{~m} / \mathrm{s} ; \mathrm{P}=0.68 \mathrm{~m})$ of the pier could be the origin of this low similarity rate. To this end, Goaziou [50] asserts that the capacity of an environment to host benthic macrofauna is linked to certain physical variables characterizing the site.

\section{Conclusion}

This work shows that the construction of the Mekin dam on the bed of the Dja River led to the warming of the water, a strong mineralization, an increase in suspended matter, and a decrease in flow velocity and dissolved oxygen in the upstream waters. These variables, coupled with the hydrological changes in the watercourse, led to an adaptation of the organisms to new hydrosystem. The environment was mostly colonized by individuals belonging to the order Odonata, family Libellulidae, with the species Trithemis dorsalis (96.05\% of the relative abundance cumulated); while downstream, the order Heteroptera, family Belostomatidae was the most abundant (55\% of the population) with the species Poissonia sp1. (79.78\% of the relative abundance cumulated); thus testifying to a progressive restoration of the hydrosystem downstream of the dam. Upstream of the dam, a restoration program should be set up in order to reduce the effects of organic pollution generated by its construction on the Dja riverbed.

Future environmental impact studies of dams constructed in aquatic environments could be carried out on i) the different compartments of the aquatic food web in order to have a baseline values of these environments prior to the construction of other hydroelectric dams. In the context of this research, this was not possible, but for others, it could facilitate the visibility of the impacts of the jetty on the benthic macroinvertebrates studied by comparing the initial state of the environment before, during and after construction of dams; ii) studies of other biological indicators (phytoplankton, zooplankton, fish...) which also characterize the state of aquatic environments could also be carried out at hydroelectric dams during their exploration, exploitation and post exploitation phases.

\section{Compliance with ethical standards}

\section{Acknowledgments}

The authors thank the authorities of the Laboratory of Hydrobiology and Environment (LHE) of the Department of Animal Biology and Physiology of the Faculty of Sciences of the University of Yaounde I for the material made available to us as well as all the students who assisted us during the sampling campaigns and during the manipulations, including: Mathias Nwaha; Janvier Kengne Tenkeu and François Désiré Owona Edoa.

\section{Disclosure of conflict of interest}

The authors declare that there is no conflict of interest regarding the publication of this document.

\section{References}

[1] Lees AC, Peres CA, Fearnside PM, Schneider M, Zuanon JAS. Hydropower and the future of Amazonian biodiversity. Biodivers. Conserv. 2016; 25(3): 451-466.

[2] Malmqvist B, Rundle S. Threats to the running water ecosystems of the world, Environ. Conserv. 2000; 29(2): 134-153.

[3] Baxter RM. Environmental effects of dams and impoundments. Ann. Rev. Ecol. Syst. 1977; 8(1): $255-283$. 
[4] Agostinho AA, Pelicice FM, Gomes LC. Dams and the fish fauna of the Neotropical region: impacts and management related to diversity and fisheries. Braz. J. Biol. 2008; 68(4): 1119-1132.

[5] Vanden Bossche JP, Usseglio-Polatera P. Characterization, ecological status and type-specific reference conditions of surface water bodies in Wallonia (Belgium) using biocenotic metrics based on benthic invertebrate communities. Hydrobiol. 2005; 551(1): 253-271.

[6] Kosmala A. Ecotoxicological evaluation of the impact of wastewater treatment plant effluents on watercourses: interest of an integrated approach. [Doctoral Thesis]. France: University of Metz. 1998.

[7] Tenkiano DSN. Benthic macroinvertebrates and aquatic hyphomycetes: diversity and in the ecosystem functioning of Guinea's rivers [Doctoral Thesis]. University of Toulouse. 2017.

[8] Micha JC, Moiset JL. Biological evaluation of the pollution of streams and rivers by aquatic macroinvertebrates, Probio Rev. 1982; 5(1): 142.

[9] Foto Menbohan S, Zébazé Togouet SH, Nyamsi Tchatcho NL, Njiné T. Benthic macroinvertebrates of the Nga river: test of characterization of a reference system by biological analyses. Eur. J. Sci. Res. 2010; 43(1): 96-106.

[10] Foto Menbohan S, Zébazé Togouet SH, Nyamsi Tchatcho NL, Ajeagah GA, Njiné. Spatial assessment of the diversity of benthic macroinvertebrate communities in an anthropized stream in a tropical environment (Cameroon). Eur. J. Sci. Res. 2011; 55(2): 291-300.

[11] Foto Menbohan S. Ecological research on the Mfoundi (Yaounde) river system: A biotypology essay. [Ph.D/ thesis]. Faculty of Sciences, University of Yaounde I. 2012.

[12] Foto Menbohan S, Tchakonté S, Ajeagah GA, Zébazé Togouet SH, Bilong Bilong CF, Njiné T. Water quality assessment using benthic macroinvertebrates in a periurban stream (Cameroon). Int. J. Biotechnol. 2013; 2: 91104.

[13] Nyamsi Tchatcho NL, Foto Menbohan S, Zébazé Togouet SH, Onana Fils M, Adandedjan D, Tchakonté S, Yémélé Tsago C, Koji E, Njiné T. Multimetric index Yaoundean Benthic Macroinvertebrate Index (IMMY) for the biological assessment of the water quality of streams in the South Central Forest Region of Cameroon. Eur. J. Sci. Res. 2014; 123(4): 412-430.

[14] Nyamsi Tchatcho NL. Benthic macroinvertebrates of the Mefou river system habitat, diversity and dynamics of the populations, assessment of the biological integrity of the rivers. [Ph.D/Thesis]. University of Yaounde I. 2018.

[15] Onana FM. Typology and biological quality of streams in the Wouri river system based on zooplankton and benthic macroinvertebrate assemblages. [Ph.D/Thesis]. University of Yaounde I. 2016.

[16] Onana FM, Tamsa AA, Tchakonté S, Koji E, Nyamsi Tchatcho NL, Nkouefuth Nfongmo Y, Zébazé Togouet SH. Effects of Industrial Agriculture and Urbanization on Structure and Functional Organization of Macroinvertebrate of Coastal Streams in Cameroon. J. Water Resour. Prot. 2021; 13: 154-171.

[17] Tchakonté S. Diversity and structure of benthic macroinvertebrate populations in urban and peri-urban streams of Douala (Cameroon). [Ph.D/Thesis]. University of Yaounde I. 2016.

[18] Kengne Fotsing J. Bio-assessment of streams in the Western region of Cameroon using benthic macrounvertebrates and construction of a regional multimetric index. [Ph.D/Thesis]. University of Lille. $2018 ; 1$.

[19] Madomguia D. Hydrobiology of two temporary streams in the Soudono-Sahelian zone: benthic macroinvertebrates of the Mayo Tsanaga and Mayo Kaliao (Far North, Cameroon). [Ph.D/Thesis]. University of Yaounde I. 2018.

[20] Biram à Ngon EB, Foto Menbohan S, Ndjama J, Nyame Mbia DLO, Mboye BR, Ajeagah GA. Ecological factors and Dictyoptera (Blaberidae) association - benthic macroinvertebrates, in some forest streams in the Centre region of Cameroon. Int. J. Adv. Res. Biol. Sci. 2018; 5(7): 235-246.

[21] Biram à Ngon EB, Foto Menbohan S, Ndjama J, Mbohou Njoya Z, Mboye BR, Dzavi J, Oumar Mahamat O, Tarkang C, Nyame Mbia DLO, Mbondo Biyong S, Ngalamou C. Water quality assessment in a less anthropogenic forest stream in the Centre region of Cameroon. Haya Saudi J. Life Sci. 2020; 5(01): 1-8.

[22] Enah DA. Characterisation of benthic macro-invertebrates: indicators of organic pollution in a urbanized area of North West Cameroon. 211p. [Ph.D/Thesis]. University of Yaounde I. 2019. 
[23] Barbour MT, Gerritsen J, Snyder BD, Stribling JB. Rapid bioassessment protocols for use in stream and wadeable rivers: periphyton, benthic macroinvertebrates and fish. 2nd edition, U. S. Environmental Protection Agency, office of water, Washington, D. C., 1999; EPA 841 - B - 99-002.

[24] Stark JD, Boothroyd KG, Harding JS, Maxted JR, Scarsbrook MR. Protocols for Sampling Macroinvertebrates in Wadeable Streams. New Zealand Macroinvertebrates working group, report no.1, Ministry for the Environment and Sustainable Management, fund project no. 5103.

[25] Durand JR, Lévêque C. Aquatic flora and fauna of Sahelo-Sudanian Africa. Tome II. Edition of ORSTOM, Paris; 1981.

[26] Diomandé D, Gourène G, Sankaré Y, Zabi SG. Synopsis of the classification of larvae and pupae of Diptera Chironomidae from freshwater ecosystems of West Africa. Keys to the determination of subfamilies, tribes and genera. Scientifics Archives of Oceanological Research Center of Abidjan. 2000; 17(1): 1-31.

[27] De Moor IJ, Day JA. Guides to the Freshwater Invertebrates of Southern Africa, Volume 6: Arachnida \& Mollusca. Chapter 3: Mollusca. Water Research Commission Report, No. TT 182/02, Pretoria-South Africa. 2002; $42-125$.

[28] De Moor IJ, Day JA, De Moor FC. Guides to the freshwater invertebrates of Southern Africa. Volume 8: Insecta II. Hemiptera, Megaloptera, Neuroptera, Trichoptera \& Lepidoptera. Prepared for the Water Research Commission, Pretoria, WRC Report No. TT 214/03. 2003; 16-71.

[29] Stals R, De Moor IJ. Guides to the Freshwater Invertebrates of Southern Africa, Volume 10: Coleoptera. Water Research Commission Report, No. TT 320/07, Pretoria-South Africa. 2007; 275.

[30] Tachet H, Richoux P, Bournaud M, Usseglio-Polatera P. Freshwater invertebrates: systematics, biology and ecology. CNRS Publishing, Paris, France. 2010.

[31] Martin P, Aït Boughrous A. Taxonomic guide to freshwater oligochaetes of the Maghreb. Ed. NUR 910, Brussels, Belgium. 2012; 12.

[32] Leclercq L. Interest and limitations of water quality estimation methods. Scientific station of Hautes-Fagnes, Belgium. 2001.

[33] Foto Menbohan S, Dzavi J, Kenfack Nzongang C, Biram à Ngon, EB, Ntchantcho R. Impact of the Anthropogenic Activities on the Diversity and Structure of Benthic Macroinvertebrates in Tropical Forest Stream. International Journal of Progressive Sciences and Technologies. 2019; 15(1): 280-29.

[34] Devidal S, Richard-Sirois C, Pouet M-F, Thomas O. Curative solutions for the restoration of lakes showing signs of eutrophication, internal report, Observatory of the Environment and Sustainable Development, University of Sherbrooke, Québec. 2007.

[35] Cabral-Oliveira J, Mendes S, Maranhão P, Pardal MA. Effects of sewage pollution on the structure of rocky shore macroinvertebrate assemblages. Hydrobiologia. 2014; 726(1): 271-283.

[36] Lecerf A. Anthropogenic disturbances and ecological functioning of headwater streams: Study of the litter decomposition process [Ph.D/Thesis]. Paul Sabatier University, Toulouse III. 2005.

[37] Moss B. The art and science of Lake Restoration. Hydrobiologia. 2007; 581: 15-24.

[38] Biram à Ngon EB. Bioecological study of aquatic dictyopterans in the Mefou watershed. [Ph.D/Thesis]. University of Yaounde I. 2019.

[39] Ngoay-Kossy JC, Zébazé Togouet SH, Wango SP, Bolevane Ouantinam SF, Tchakonté S, Piscart C. Bioindicators of lotic aquatic environments in the Central African Republic: benthic macroinvertebrates and anthropogenic pressure in the Nguitto stream. J. Ecol. (Earth and Life). 2018; 73(4): 603-616.

[40] Horeau V, Cerdan Ph, Champeau A. The impoundment of the Petit-Saut hydroelectric dam (French Guiana): its consequences on aquatic invertebrate populations and fish food. Hydroecol. Appl. 1997; 1-2(9): 213-240.

[41] Milot S. Monitoring the biological health of the Chute stream. Federation of Lakes of Val-des-Monts; 2020.

[42] GSED: Green Spaces and Environment Department. Target species in Paris: Odonates. Aquatic subframe. 2017; 1.

[43] Polhemus JT. Hemiptera (True Bugs). In: Gene E. Likens, Encyclopedia of Inland Waters. $1^{\text {st }}$ ed. Academic Press: London; Boston. 2009; 323-334. 
[44] Schriever TA, Bogan T, Boersma M, Cañedo-Argüelles KS, Jaeger M, Olden KL, Lytle, DA. Hydrology shapes taxonomic and functional structure of desert stream invertebrate communities. Freshw. Sci. 2015; 34(2): 399409.

[45] Dieterich M. Insect community composition and physico-chemical processes in summer dry streams of western Oregon. [Ph.D/Thesis], Oregon State University, Corvallis OR. 1992.

[46] Dieterich M, Anderson NH. Life cycles and food habits of mayflies and stoneflies from temporary streams in western Oregon. Freshw. Biol. 1995; 34(1): 47-60.

[47] Mazzacano C, Hoffman BS. Aquatic Using Aquatic Macroinvertebrates as Indicators of Stream Flow Duration. The Xerces Society for Invertebrate Conservation, Portland OR. 2008.

[48] Kapoor-Vijay P, White J. Conservation biology a training manual for biological diversity and genetic resources. London: Commonwealth Science Council. 1992; 71-85.

[49] Evrard M. Use of nymphal exuviae of Chironomidae (Diptera) as biological indicators of the quality of Walloon surface waters. [Doctoral thesis], Our Lady of Peace University Faculties Belgium. 1996.

[50] Goaziou Y. Methods for assessing the biotic integrity of the aquatic environment based on benthic macroinvertebrates. Internship report. 2004; 50. 